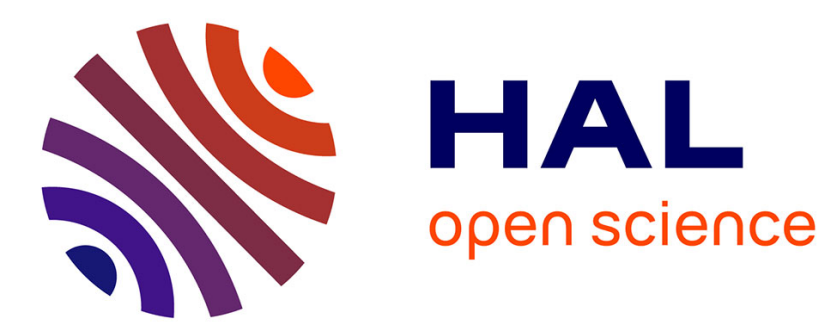

\title{
Fact-type complements in Gbe and the Surinamese Creoles Fact-type Complements in Gbe and the Surinamese Creoles
}

\author{
Bettina Migge, Donald Donald
}

\section{To cite this version:}

Bettina Migge, Donald Donald. Fact-type complements in Gbe and the Surinamese Creoles Fact-type Complements in Gbe and the Surinamese Creoles. Lingua, 2013, 129 (7), pp.9-31. 10.1016/j.lingua.2012.03.006 . hal-01495059

\section{HAL Id: hal-01495059 \\ https://hal.science/hal-01495059}

Submitted on 24 Mar 2017

HAL is a multi-disciplinary open access archive for the deposit and dissemination of scientific research documents, whether they are published or not. The documents may come from teaching and research institutions in France or abroad, or from public or private research centers.
L'archive ouverte pluridisciplinaire HAL, est destinée au dépôt et à la diffusion de documents scientifiques de niveau recherche, publiés ou non, émanant des établissements d'enseignement et de recherche français ou étrangers, des laboratoires publics ou privés. 


\section{Research Repository UCD}

Provided by the author(s) and University College Dublin Library in accordance with publisher policies. Please cite the published version when available.

\begin{tabular}{|c|c|}
\hline Title & Fact-type complements in Gbe and the Surinamese Creoles \\
\hline Author(s) & Migge, Bettina; Winford, Donald \\
\hline $\begin{array}{c}\text { Publication } \\
\text { date }\end{array}$ & 2013-05 \\
\hline $\begin{array}{l}\text { Publication } \\
\text { information }\end{array}$ & Lingua, 129 (May 2013): 9-31 \\
\hline Publisher & Elsevier \\
\hline $\begin{array}{l}\text { Item } \\
\text { record/more } \\
\text { information }\end{array}$ & http://hdl.handle.net/10197/5837 \\
\hline $\begin{array}{l}\text { Publisher's } \\
\text { statement }\end{array}$ & $\begin{array}{l}\text { This is the author's version of a work that was accepted for } \\
\text { publication in Lingua. Changes resulting from the publishing } \\
\text { process, such as peer review, editing, corrections, structural } \\
\text { formatting, and other quality control mechanisms may not be } \\
\text { reflected in this document. Changes may have been made to } \\
\text { this work since it was submitted for publication. A definitive } \\
\text { version was subsequently published in Lingua (VOL } 129 \text {, } \\
\text { ISSUE 2013, (2013)) DOI: } 10.1016 / j \text {.lingua.2012.03.006 }\end{array}$ \\
\hline $\begin{array}{l}\text { Publisher's } \\
\text { version (DOI) }\end{array}$ & http://dx.doi.org/10.1016/j.lingua.2012.03.006 \\
\hline
\end{tabular}

Downloaded 2017-03-21T20:10:45Z

The UCD community has made this article openly available. Please share how this access benefits you. Your story matters! (@ucd_oa)

Some rights reserved. For more information, please see the item record link above. 


\title{
Fact-type Complements in Gbe and the Surinamese Creoles
}

\author{
Bettina Migge, University College Dublin \\ Donald Winford, the Ohio State University
}

\begin{abstract}
Although several researchers have suggested that fact-type complementation in the Surinamese Creoles is modeled on that of their main input languages, the Gbe languages, we still lack precise information on the extent of the similarities and differences. In this paper we provide a broad comparison of fact-type complementation in these two language groups and suggest an explanation for the similarities we find. We explore the syntax and semantics of the complementizers used in both language groups, the kinds of complement-taking predicator (CTP) that select these complements and their syntax and semantics. The analysis reveals close structural and functional similarities between the two language groups suggesting that fact-type complementation in the Surinamese Creoles was largely modeled on that of Gbe.
\end{abstract}

Keywords: Complementation, substrate influence, fact-type complements, quotative, grammaticalization

\section{Introduction.}

Our goal in this paper is to compare fact-type complements in the Gbe languages and the Surinamese Creoles, with a view to determining how far the former languages may have influenced the grammar of complementation in the latter. Crosslinguistically, the number of complement clause types found in the world's languages range from just one in languages like Jarawara and Goemai, two in languages like Akkadian and Irish, to four in Tariana, five in White 
Hmong, six in Israeli and seven in English and Pennsylvania German. But there are three recurring types that are found crosslinguistically (Dixon 2006:23):

- Fact-type complements, which refer to the fact that something has occurred, is occurring, or will occur, e.g., I know that Kim has left.

- Activity-type complements, which refer to an ongoing activity or event, e.g., I saw Kim leave.

- Potential-type complements, which refer to the potentiality of the subject of the complement becoming involved in some activity or situation, e.g., I want Kim to leave.

These are also the major types of complement types that are found in Gbe and the Surinamese Creoles. ${ }^{1}$

While there has been a considerable amount of recent research investigating the influence of Gbe languages on various aspects of Surinamese Creole grammar (cf. Migge and Smith 2007; introduction to this volume), the contribution of Gbe languages to the grammar of complementation in the Surinamese Creoles has received comparatively little attention and has focused primarily on potential-type complements in Saamaka. For instance, Byrne (1987) discusses various potential-type complements introduced by $f u$ in Saamaka, and argues that $f u$ in this function is in fact a second verb (V2) in a serial verb construction, and that fu complements are similar to other serial verb structures in the language. Though he does not directly compare

\footnotetext{
${ }^{1}$ These complement types are also found in Akan, another of the substrate languages involved in the formation of the Surinamese Creoles. The range of 'say' complements found in Akan closely matches those found in Gbe and the Surinamese creoles (see Boadi 2005; Osam 1998). However, in this paper we only focus on comparing 'say'-complements in the Surinamese Creoles with those of their primary substrate, the Gbe languages.
} 
potential complements in Saamaka with those in its West African substrates, he accepts Bickerton's (1984) language bioprogram account of creole formation, and concludes that serialization (and by implication $f u$ complementation) "is a spontaneous outgrowth of radical creolization, rather than due to any W. African influence" (1987:252). More recent discussions of $f u$ take a different approach to this issue. Lefebvre and Loranger (2006) argue that $f u$ is a multifunctional element that functions as a preposition, a complementizer, a mood marker and possibly as a case marker. While there is some overlap between $f u$ in Saamaka and for in English, their three-way comparison reveals very close similarities between the uses of $f u$ in Saamaka and ni/nu in Fongbe (Fon). This leads them to reject Byrne's (1987) language bioprogram account. Instead, they argue that $f u$ was associated with $n u / n i$ through the mechanism of relexification and thus acquired with the lexical entry of its substrate counterpart. A broadly similar view is taken by Aboh (2006), who builds on Damonte's (2002) discussion of $f u$ and táa in Saamaka, which he labels 'subjunctive' and 'declarative' complementizers respectively. Focusing on potential-type complements in Saamaka and Gungbe (Gun), Aboh argues that the close similarities between the two languages in this area suggest that Gun ní influenced the properties of Saamaka $f u$. His account posits that both languages have a single multi-functional item ( $f u$ in Saamaka and ní in Gun) which encodes irrealis mood as head of a Force Phrase, and expresses deontic modality under Fin(iteness).

As far as fact-type complements are concerned, Byrne (1987) and Veenstra (1996) provide brief discussions of them for Saamaka, while Plag $(1993,1995)$ offers a more detailed look at both fact-type and potential-type complements in Sranan on the basis of diachronic as well as contemporary data. Byrne argues that complementizer táa, which introduces fact-type complements in Saamaka, is a reduced form of taki 'say, but is essentially a serial verb in the 
most conservative varieties of Saamaka, though it appears to have undergone some degree of reanalysis as a complementizer in certain contexts, for example in complements to evaluative predicates like fanondu 'important.' As in the case of potential-type complements, Byrne appeals to a language bioprogram explanation for the emergence of táa in this function, and rules out the possibility of West African influence. Veenstra (1996) also argues that complementizer táa was previously a V2 in a serial verb construction, but notes that its reanalysis as a complementizer was "due to a diachronic process internal to the language itself" (1996:154). He does not consider the possibility of West African substrate influence as a factor in this development, though he does acknowledge that possibility in the case of the grammaticalization of $d a$ 'give' into a dative preposition, on the model of substrate items such as Ewe na 'give'. With regard to Sranan, Plag (1993, 1995) argues for a grammaticalization process in which taki 'say' is reanalyzed from a main verb to quotative verb to a complementizer. He also notes that there are important similarities between the use of bé 'say' as a complementizer in Gbe [Ewe] and taki in the same function in Sranan, but does not provide a detailed comparison. He concludes that both substrate influence and internal developments played a role in the emergence of the various grammatical functions of taki. ${ }^{2}$ Both Plag (1993) and van den Berg (2007) also show that in Sranan Tongo, unlike the other Creoles of Suriname, the fact-type complementizer taki competes with dati (< Dutch dat). The use of dat $(i)$ as complementizer in Sranan Tongo is likely to be due to sustained contact with Dutch because Dutch also uses dat as a complementizer.

\footnotetext{
${ }^{2}$ Plag also points to parallels with the Kikongo complementizer vo, which may have originated from the verb vova 'say' (1993:157), but suggests that relating 'say' in the creoles to vo might be difficult because it also functions as a demonstrative pronoun.
} 
Substrate influence is, however, posited as a crucial factor in the emergence of the 'say' complementizer by Migge (1998) for the Eastern Maroon Creole, and by McWhorter (1992) and Lefebvre and Loranger (2008) for Saamaka. Examining constructions involving 'say' functioning as a complementizer in Saamaka and the Eastern Maroon Creole respectively, all three authors demonstrate that the uses of taki and táa closely resemble their counterparts in West African languages, particularly those from the Kwa family of languages. McWhorter (1992) concludes that "although there are obvious universal influences on SVC [serial verb construction] formation, the SVCs in SA [Saamaka] most closely resemble the Kwa/Nigerian ones." (1992:44). Lefebvre and Loranger (2008) go even further in that they show that the similarities extend beyond the complementizer function; táa and its Fon counterpart also show the same behavior in its other functions and in its distribution. We will come back to this below.

Research on fact-type complementation in African languages has mostly focused on how such constructions arose. These studies typically suggest that fact-type complementizers arose gradually from verbs meaning 'say' through processes of grammaticalization. Lord $(1976,1993)$ and Heine and Reh (1984) argue that complementizer 'say' arose via reanalysis of an erstwhile V2 in a variety of West African languages including Gbe, while Kinyalolo (1993) argues that the putative complementizer $\not \grave{\jmath}$ in Fon still functions as a V2 that selects a CP complement headed by a phonologically null complementizer.

So far, however, there has been only one systematic comparison of fact-type complements in Fon and Saamaka, by Lefebvre and Loranger (2008). There has been no attempt at a more comprehensive comparison of this complement type in a sample of Gbe languages and the Surinamese Creoles. Hence we do not know how far the two language groups are similar, for 
instance, in the range of complement types in which 'say' appears, the syntax of 'say' complements, and the relationships among the various grammatical functions of 'say.'

Our goal in this paper is to provide a detailed comparison of this complement type in the two language groups. We will focus on two broad issues, first, whether and to what extent there are parallel grammatical functions associated with 'say' in Gbe and the Surinamese Creoles, and second, the degree of similarity in the grammar of 'say' complements in the two language groups. To this end, we will attempt to answer the following questions:

- Do the two groups of languages share the same set of complement clause types, and the same set of CTPs?

- Do the CTPs in both language groups fall into the same semantic types, with the same subcategorization properties (i.e. the same restrictions on the types of complement they take)?

- Do the 'say' verbs/complementizers share the same range of functions? Have they been subject to similar processes and paths of grammaticalization, whether internally or externally motivated?

- Do the complement types themselves share similar syntactic properties?

In order to investigate these issues, we examined transcribed recordings of natural conversational interactions for three Surinamese Creoles (Sranan Tongo (SN), and the Eastern Maroon varieties (EMC) Pamaka (PM) and Ndyuka (ND)) and for five varieties of the Gbe cluster of languages (Ajagbe (Aja), Gengbe (Gen), Maxigbe (Maxi), Wacigbe (Waci), Xwelagbe (Xwela), Xwlagbe (Xwla)). We also used some elicited data from these varieties and from Ewegbe (Ewe) and 
Saamaka. ${ }^{3}$ Finally, we also draw on examples from the published literature which mostly deals with Saamaka, Sranan Tongo, Gun and Fon. ${ }^{4}$

The rest of this paper is organized as follows. Section 2 briefly describes the set of complement-taking predicates in the two language groups and introduces complementizer 'say'. Section 3 describes the various functions of 'say', which range from main verb to quotative to a V2-like quotative to a complementizer introducing object, subject and other complement types, to a subordinator introducing clauses of purpose and consequence. Section 4 discusses the syntactic aspects of fact-type complements in the two languages and section 5 provides a summary of our findings. In section 6 , we argue that the similarities between Gbe and the Surinamese creoles are due to substrate influence. We discuss various hypotheses about the role of substrate influence in creole formation, and appeal finally to van Coestsem's notion of imposition to explain the similarities in the grammar of Fact-type complements in the two language groups.

\section{Complement taking predicates and fact type complements.}

Fact-type complements usually refer to some event or situation that took place, or is taking place, or has the potential to take place. Noonan (1985:92) refers to them as "Indicative-type"

\footnotetext{
${ }^{3}$ Most of the data for Ewe was kindly supplied by Felix Ameka (University of Leiden).

${ }^{4}$ For the purposes of this paper, we mostly rely on data from Fon and Ewe, which are the most widely studied of the Gbe languages, and which are widely taken to be representative of the Eastern and Western Gbe clusters respectively. Where possible, we also employ data from other varieties of Gbe, indicating differences where relevant.
} 
complements, noting that they typically have independent time reference, i.e., "the time reference of the complement is in no way logically bound by the time reference of the matrix predicator" (1985:92). In Gbe and the Surinamese Creoles, as in other languages, such complements include arguments of assertion verbs ('say', 'tell', etc.); of psyche state verbs ('know', 'believe', etc.); of perception verbs ('see', 'hear', etc.); and of emotive predicates such as 'fear', 'like' etc. As Dixon (2006:10) points out, these constitute the prototypical complementtaking verbs in every language. In these cases, the complement can be analyzed as a sentential complement that functions as the grammatical object of the CTP. Other classes of predicates which select object complement clauses include desiderative verbs such as 'hope', 'wish' etc.; and verbs of inquiry such as 'ask', 'find out' etc. Fact-type complements can also function as extraposed subjects of predicates like 'seem'; evaluative or commentative predicates such as 'good, true, important' etc; and modal-type predicates such as "necessary", "possible", and others. Note, in addition, that some CTPs can select other types of complement (e.g., Potentialtype or Activity-type complements) as well. Table 1 provides examples of the various types of CTP that select Fact-type complements in English, the Creoles of Suriname and varieties of Gbe.

Table 1: Examples of CTPs selecting Fact-type complements as objects in the Surinamese Creoles and Gbe.

\begin{tabular}{|l|l|l|}
\hline CTPs & $\begin{array}{l}\text { CTPs in the Creoles of Suriname } \\
\text { (English) }\end{array}$ & CTPs in varieties of Gbe \\
& Tongo $)$ & \\
\hline \multicolumn{2}{|l|}{ Utterance Predicates } & \\
\hline
\end{tabular}




\begin{tabular}{|c|c|c|}
\hline $\begin{array}{l}\text { Speaking: say, tell, } \\
\text { report, inform, lie, } \\
\text { explain, persuade }\end{array}$ & $\begin{array}{l}\text { taki }(\mathrm{EMC} / \mathrm{SN})^{5} \text {, táa }(\mathrm{SM}) \text { ‘say', } \\
\text { taagi }(\mathrm{EMC}) / \text { taigi }(\mathrm{SN}), \text { fan }(\mathrm{SM}) \\
\text { 'tell', ley 'lie', }\end{array}$ & $\begin{array}{l}\text { gblo, dó (Ewe), dう̀ (Fon) } \\
\text { 'say', tsi, tó 'tell'(Ewe) } \\
\text { da alakpa; ká asatso 'lie' } \\
\text { (Ewe), zòn 'order' (Fon) } \\
\text { фう̀ nú 'order' (Fon) }\end{array}$ \\
\hline $\begin{array}{l}\text { verbs of enquiry: } \\
\text { ask }\end{array}$ & $\begin{array}{l}\text { akisi (EMC)/ aksi (SN), hákísi (SM) } \\
\text { 'ask' }\end{array}$ & biá (Ewe), bìyó (Fon) 'ask' \\
\hline $\begin{array}{l}\text { Promising: } \\
\text { promise, threaten }\end{array}$ & $\begin{array}{l}\text { paamisi (EMC), pramisi }(\mathrm{SN}), \\
\text { paamúsi }(\mathrm{SM}) \text { 'promise' }\end{array}$ & $\begin{array}{l}\text { dó yugbe (Ewe) 'promise' } \\
\text { dó voṽ̃ } \mathrm{X} \text { (Ewe) 'threaten } \\
\mathrm{X} \text { ' }\end{array}$ \\
\hline \multicolumn{3}{|c|}{ Perception Predicates } \\
\hline $\begin{array}{l}\text { Perception: see, } \\
\text { hear, notice, smell, }\end{array}$ & $\begin{array}{l}\text { si 'see', } \\
\text { yee (EMC)/yere (SN) 'hear', } \\
\text { sumee }(\mathrm{EMC}) / \text { smeri }(\mathrm{SN}), \text { sumee } \\
(\mathrm{SM}) \text { 'smell', }\end{array}$ & $\begin{array}{l}\text { kpó 'see' (Ewe), mò 'see’ } \\
\text { (Fon), } \\
\text { kpódzesi (Ewe) 'notice', se } \\
\text { (Ewe), sè (Fon) 'hear', }\end{array}$ \\
\hline \multicolumn{3}{|c|}{ Cognitive Predicates } \\
\hline Thinking: think, & denki 'think', & $b u$ (Ewe), lin (Fon) 'think, \\
\hline
\end{tabular}

${ }^{5}$ SM stands for Saamaka, SN stands for Sranan Tongo, ESN: Early Sranan, EMC for Eastern Maroon Creoles, ND for the Eastern Maroon Creole variety of Ndyuka and PM for the Eastern Maroon Creole variety of Pamaka. 


\begin{tabular}{|c|c|c|}
\hline $\begin{array}{l}\text { imagine, dream, } \\
\text { assume, suppose }\end{array}$ & $\begin{array}{l}\text { paskise(l)i (EMC/SM), pakiseri (SN) } \\
\text { 'think' } \\
\text { membe(e) (EMC), membre (SN), } \\
\text { mëni (SM) 'think, remember', } \\
\text { feegete (EMC)/ fergete (SN), 'forget' } \\
\text { biibi (EMC/SM), bribi (SN) } \\
\text { 'believe' } \\
\text { leiki (EMC), 'consider, think' } \\
\text { bereken / reken (SN) 'consider, } \\
\text { think' }\end{array}$ & $\begin{array}{l}\text { consider, calculate' } \\
\text { wì (Fon) 'believe', } \\
x \text { (e)se [get 3sg hear] (Ewe) } \\
\text { 'believe', } \\
\text { flìn (Fon) 'remember', } \\
\text { dó gkú (é)dzí '[set eye ( } 3 \mathrm{sg}) \\
\text { top] (Ewe) 'remember' } \\
\text { kú drõe (Ewe) 'dream' } \\
\text { ylo bé (Ewe) 'forget' }\end{array}$ \\
\hline $\begin{array}{l}\text { Knowledge: know, } \\
\text { understand, } \\
\text { suspect }\end{array}$ & $\begin{array}{l}\text { sabi (EMS/SN), sá (SM), yee (EMC) } \\
\text { 'know', } \\
\text { fustan (EMC), ferstan (SN), fusután } \\
\text { (SM) 'understand' }\end{array}$ & $\begin{array}{l}\text { nyá (Ewe), tùn (Fon) 'know' } \\
\text { se (x) gome [hear (3sg) } \\
\text { under] (Ewe) 'understand' }\end{array}$ \\
\hline \multicolumn{3}{|l|}{ Desiderative } \\
\hline $\begin{array}{l}\text { ask (request) } \\
\text { tell (order) }\end{array}$ & $\begin{array}{l}\text { wani }(\mathrm{EMC} / \mathrm{SN}), k \varepsilon(\mathrm{SM}) \text { 'want' } \\
\text { hop }(u) \text { 'hope' } \\
\text { akisi (EMC)/aksi (SN) 'ask' } \\
\text { taagi (EMC)/taigi (SN) }\end{array}$ & $\begin{array}{l}\text { dí (Ewe), jló (Fon) 'want', } \\
\text { bà (Fon) 'wish' } \\
\text { kpómó [see road] (Ewe) } \\
\text { 'hope' } \\
\text { biá (Ewe) 'ask' } \\
\text { qe gbe [remove voice] (Ewe) } \\
\text { 'order' }\end{array}$ \\
\hline
\end{tabular}




\begin{tabular}{|c|c|c|}
\hline \multicolumn{3}{|l|}{ Emotive } \\
\hline $\begin{array}{l}\text { like, love, regret, } \\
\text { fear/be afraid, } \\
\text { sorry, glad, sad }\end{array}$ & $\begin{array}{l}\text { lobi 'like, love', } \\
\text { feele (EMC), frede (SN), fëeё (SM) } \\
\text { 'afraid' } \\
\text { poolo (EMC/SM) / breiti (EMC/SN) } \\
\text { 'be happy' } \\
\text { sari 'sorry' }\end{array}$ & 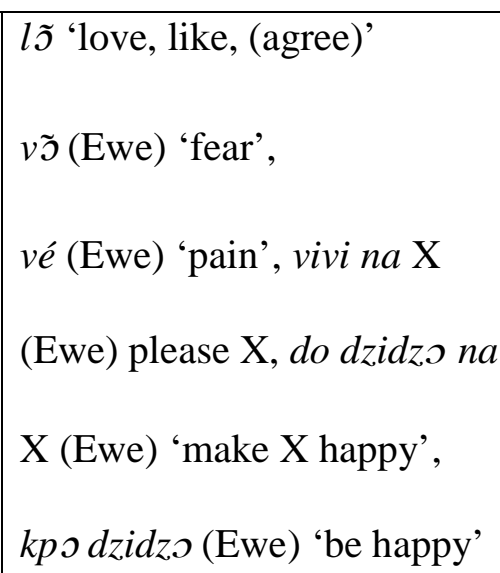 \\
\hline \multicolumn{3}{|l|}{ Evaluative } \\
\hline $\begin{array}{l}\text { true, sad, important } \\
\text { etc. }\end{array}$ & $\begin{array}{l}\text { tru }(\mathrm{SN}), \text { tuu (EMC), tuútuu }(\mathrm{SM}) \\
\text { 'true', } \\
\text { belangrijk 'important' (SN, EMC, } \\
\mathrm{SM}) \\
\text { sari (SN), tyali (EMC), tjali (SM) } \\
\text { 'be sad' }\end{array}$ & $\begin{array}{l}\text { nyó(Fon) 'be good', } \\
\text { víní (Fon) 'be nice', le vevie } \\
\text { (Ewe) 'be important' }\end{array}$ \\
\hline \multicolumn{3}{|l|}{ Modal predicates } \\
\hline possible, necessary & $\begin{array}{l}\text { kan de 'be possible' (SN) } \\
\text { musu (de) 'must (be)' (SN, EMC, } \\
\mathrm{SM}), \\
\text { mu de 'should (be)' (EMC) } \\
\text { de fanowdu 'be necessary' (SN, } \\
\text { EMC, SM) }\end{array}$ & $\begin{array}{l}\text { tíy nyí 'be possible' (Waci) } \\
\text { hyã '(be) necessary' (Waci) }\end{array}$ \\
\hline seem, appear & gersi $(\mathrm{SN})$, geli $(\mathrm{EMC}, \mathrm{SM})$ & $c i ́$, dì (Fon), wo, dzé (Ewe) \\
\hline
\end{tabular}


\begin{tabular}{|l|l|l|}
\hline & 'seem, appear' & 'seem, appear' \\
\hline
\end{tabular}

*Note that some of the desiderative, emotive, and interrogative verbs also take Potential-type complements.

Table 1 suggests that the range of CTPs that take fact-type complements in Gbe languages, English and the Surinamese Creoles is quite similar.

In both Gbe and the Surinamese Creoles, sentential complements of verbs belonging to these subclasses are introduced by a complementizer that is homophonous with a verb meaning 'say', taki in Sranan Tongo and the Eastern Maroon Creoles, táa in Saamaka, bé in Gen, varieties of Ewe and Xwla, bó in Waci, $q \zeta$ in varieties of Fon, mó in Aja, and fá in Xwela.

$\begin{array}{rlllllll}\text { (1) a. PM } & \text { Den } & \text { sab } & \underline{\text { taki }} & u & \text { ala } & \text { na famii oo. } \\ & \text { they know } \text { COMP }^{6} & \text { we all } & \text { COP family EMP }\end{array}$

'They know that we are all members of the same family!'

\footnotetext{
${ }^{6} \mathrm{We}$ use the following abbreviations: COMP: complementizer, COP: copular, COR: coordinator, DAT: dative object, DEF:definite, DEM: demonstrative, DET: determiner, EMP: emphatic, FOC: focus marker, FUT: future, HAB: habitual, IMPF: imperfective, IMPERS: impersonal, INTER: interrogative marker, INTERJ: interjection, JUSS: jussive, LINK: linking element, LOC: locational marker, LOG: logophoric pronoun, NEG: negation, NUMB: number, OBL: (weak) obligation, PAST: past, PL: plural, POT: potential mood, PROG: progressive, PROSP: prospective, QV: quotative verb, RECIP: recipical, REP: repetitive aspect, SUB: subjunctive, SRP: subject referencing pronoun, TMA: tense, mood, aspect marker, TP: topic.
} 
b. Gen Mi nyã bé agba gbã. (Gen NSF 3)

we know COMP baggage break

'We know that the luggage is destroyed.'

While all appear to historically derive from a verb meaning 'say', most of them are no longer fully-fledged main verbs. Bé in Ewe, Gen, Xwla, bó in Waci, fá in Xwela, mó in Aja and táa in Saamaka can still appear in a main verbal slot but do not take the full range of Tense, Mood and Aspect (TMA) markers any more, appearing mostly without any TMA marking or with the future or potential marker in the conversational recordings. In their stead we find other verbs meaning 'say' (gblo in Ewe, gblõ in Gen and Waci, ló in Xwela and Xwla, nú in Aja, taki in Saamaka) that can take the full range of TMA markers, especially in contexts requiring TMA marking. Only taki in the Surinamese Creoles (Sranan Tongo and Eastern Maroon varieties) and dó in eastern Gbe varieties such as Gun, Fon, Maxi are fully verbal main verbs that can also function as V2s in serial verb constructions.

In the following section, we compare the range of functions of 'say' in the Gbe languages and the Surinamese Creoles. Our findings reveal that this range of functions - from main verb to quotative to complementizer - is remarkably similar in the two language groups. We treat these functions as linked in a grammaticalization chain that is very similar to other cases of the grammaticalization of 'say' crosslinguistically. Based on this evidence, we conclude that 'say' in both language groups can best be interpreted as an erstwhile verb that was reanalyzed as a complementizer in a serial verb construction context, though it still preserves its verbal status in certain uses. 


\section{The functions of 'say' in Gbe and the Surinamese Creoles}

Plag $(1992,1995)$ offers the first detailed attempt at describing the various functions of taki 'say' in Sranan. Much of his description is in accord with our own findings. For instance, he points out that taki is used in the following functions:

- a main verb,

- a quotative element introducing direct speech,

- a complementizer introducing indirect speech or some other proposition,

- a complementizer introducing complements to verbs other than verba dicendi

- a complementizer introducing extraposed subject complements.

- a subordinator introducing purpose clauses.

Plag also discusses the possibility that Ewe bé 'say' is a possible model for taki, noting that the former "introduces clauses that express propositional or cognitive content as well as extraposed subject clauses, purpose and consecutive clauses" (1995:138). However, he does not provide examples or attempt a full comparison between Ewe and Sranan. In the following discussion, we provide further details and illustration of the similarities in the functions of 'say' in the Gbe languages and the Surinamese Creoles.

The use of taki/táa as a main verb is found in all of the Surinamese Creoles, as illustrated in (2):

(2) a. PM $U$ mu man taki ala sani. we must can say all thing

'We should be able to say everything [as it is].'

b. SM Eside mi baa táa di wata bi koto. 
Yesterday my brother say DET water PAST cold

'My brother said that the water was cold yesterday.'

c. SM Eside, mi baa taki táa di wata bi kendi a di Yesterday my brother say COMP DET water PAST hot LOC DET oto eside.

other yesterday.

'Yesterday my brother said that the water was hot the day before yesterday.'

Similarly, in Fon, q' 'say' functions as a main verb, as in the following example from Lefebvre and Brousseau (2002:115):

(3) Fon Yé dó xó víví víví nú Sika.

they say word sweet sweet to Sika

'They said very sweet words to Sika.'

$B e ́$ in Ewe can also appear as a main verb in some contexts, but is otherwise usually replaced by gblo 'say' in present day Ewe. ${ }^{7}$

\footnotetext{
${ }^{7}$ According to Ameka (pc 2010), the uses of main verbal bé in Ewe now appear to be limited to contexts where it introduces questions and direct and indirect speech (4) and it can co-occur with only certain TMA markers, such as the Potential and the Repetitive marker.
} 
(4) Ewe é-ga-bé nú ka?

she-REP-say thing INTER

'She says what again?' (Ameka 2005: 7)

In addition, 'say' performs a quotative function as a main verb that introduces direct speech in both the Surinamese Creoles and Gbe languages.

(5) a. ND $A$ e taki: "u tya u sani go a tapu, da u $e$ boli." she IMPF say you carry your thing go LOC top then we IMPF cook 'She says "Bring the stuff upstairs then we'll cook.'

b. SN Dagu taki, "No man, mi dati no o slakti mi meti ete". dog say no INTERJ I EMP NEG FUT butcher I animal yet Dog said, "No way man, I'm not going to butcher my animal yet".

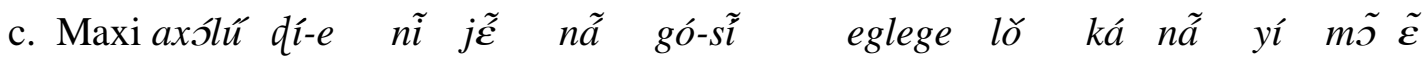
Axolu is-this me only FUT leave-from field COR ? FUT go see him 'As for Axolu, it is only me who will leave the field and visit him

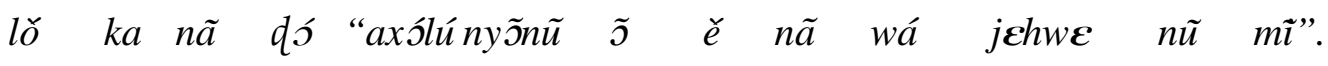
COR ? FUT say Axolu woman DET PL FUT come complain DAT me 'And will say: Axolu, to me the woman will come to complain.'

d. Ewe Tsitsi-a-wó bé: “wó-nyá-ná hã wó-ga-biá-nâ". elder-DEF-PL say they-know-HAB also they-REP-ask- HAB 'The elders say: "even though one knows, one still asks" (Ameka, pc 2010) 
In a similar use, 'say' also functions as a quotative V2 in a serial verb construction where the V1 is either 'say' itself, or some other speech act verb, or a verb of cognition, such as 'think'.

(6) a. SN Now anansi prakseritaki: "So, dan now mi o go, meki wan moni, now spider think QV so then now I FUT go make a money now". now

'So then Spider thought, "Now I will go and make some money.'

b. Ewe Mí-gblo-na bé: elā yia fía míe-dzrá-ge 500. we-say- HAB QV fish DEM now we-sell-PROSP 500 'We say: this fish we are going to sell it for 500 cedis.'(Ameka 2005: 7)

These uses of 'say' reflect a pattern found across many other languages, where, as Klamer (2000:75) notes, “...'quotative' or 'report' constructions are described as expressing speech acts and mental/physical perception." In some languages, 'say' is typically set off from the quoted speech (or thought) by a pause or intonational break that may be represented in the transcribed data by a comma or colon immediately following 'say'. In Gbe varieties there does not appear to be an intonational break in this place, but all researchers agree that in these cases 'say' denotes an act of speaking and is verbal. This applies whether it is the only verb, or functions as the V2 in a serial structure. Also of interest here is the fact that there are constructions in which quotative 'say' is preceded by a pronominal subject (and a conjunction), assigning the two verbs in a series to two different clauses. Strictly speaking, they are not SVCs but they are functionally equivalent. Lefebvre and Brousseau (2002:539) provide the following example from Fon: 
(7) Fon Àxo-ví Àwilìnkponúwà dó lò $n u$ to $\quad$ tòn ...

Princess Awinkponuwa produce anecdote for father GEN ...

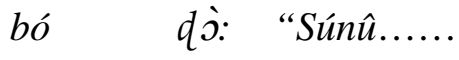

and.she say: "Man...

'Princess Awinkponuwa told a story to her father .... and she said: "The man.....

This strategy is also found in the Surinamese Creoles, as in the following example from Pamaka.

(8) $\mathrm{PM}$ A gi mi a hii toli, a taki...

he give me DET whole story. he say

'He told me the whole story, he said...'

The texts of Herskovits and Herskovits (1936) contain many similar uses of a resumptive pronominal subject appearing before quotative taki in Sranan, as in the following example:

(9) $\mathrm{SN} \quad \mathrm{Na}$ papa piki hem, a taki, "Luku so wan bigi grong mi habi."

DET papa answer him he say: look so one big field I have

'The papa answered her, he said, 'Look, I have so large a field.'

(Herskovits and Herskovits 1936:232-3, quoted in Plag 1992:58). 
Plag (1992:62) points out that all of the examples of quotative taki in Schumann's (1783) dictionary are of this type. This may suggest that loss of the pronominal subject may have been a factor in the reanalysis of quotative taki as a complementizer. (See above)

A third function of 'say' that is shared by all the Surinamese Creoles and all the Gbe languages is to introduce reported speech or thought, either as the sole verb in the report frame, or as V2.

(10) a. PM A taki a sani án moi.

she say DET thing NEG pretty

'S/he says that the thing isn't pretty.'

b. SN Want ala sma o taki a sani diri.

because every person FUT say DET thing expensive

'Because everybody will say that things are expensive.' (Tape 45A. line 125)

c. Ewe Me-be me-wo-e.

I-say I-do-it

'I said, "I did it”, OR 'I said that I did it.' (Ameka, pc 2010)

d. SN A taagi mi taki $i$ no $e$ nyan fisi.

he tell me COMP you COMPIMPF eat fish

'He told me that you don't eat fish.'

e. Ewe Kofi gblo bé ye-dzo.

Kofi say QV_COMP LOG-leave

'Kofi said that he has left.' (Ameka, pc 2010) 
Structures like the latter seem to represent a pivotal point in the conversion of 'say' from verbal to complementizer status. In these and other cases discussed below, 'say' is not separated from the reported segment by a pause, and this favors its reinterpretation as part of the complement clause. In the examples just given, the quotative and complementizer functions of 'say' seem to overlap, and are not easily distinguishable. At this point, as Chappell (2008:60) observes in connection with 'say' in Sinitic languages, “ a new inference concerning grammatical meaning becomes available for the semantically generic quotative V2 'say', enabling a simultaneous interpretation as a linking mechanism which introduces the following clause, while not cancelling out its lexical sense."

A further stage in this process involves the use of 'say' to introduce sentential complements of predicates that are not verba dicendi, such as cognitive, emotive, and similar verbs depicting states of mind.

(11) a. SN Mi sabi taki yu no e nyan pataka.

I know COMP you NEG IMPF eat type-of-fish

'I know that you do not eat pataka'

b. PM A feele taki den o post en. she be.afraid COMP they FUT send her

'She's afraid that they will send her back.'

c. Gen o nyán bé né o no móto-me káká kosídá vo [...],

they know COMP if you stay car-in until week finish

o lá lé do, [...]

you FUT catch sickness 
'They know that if you stay in the car until the end of the week you get sick.'

In both language groups, 'say' also introduces complements to perception verbs.

(12) a. SN Ma yu kan si taki a man don fosi.

But you can see COMP DET man dumb before

'But you can see that the guy was stupid then.'

b. Fon $E^{\prime} m \grave{\jmath}$ djo ví ó yàví.

s/he see COMP child DEF cry

'(S)he saw that the child cried.'

(Tossa 1994: 181, in Lefebvre and Brousseau 2002:543)

It is clear that, in its uses with cognitive and perception verbs, 'say' is no longer used just to introduce reported speech, but different kinds of propositions. In such constructions, 'say' is more or less "bleached" of its original semantic content, or as Chappell (2008:60) puts it: "The original lexical meaning of V2 ['say'] is incompatible with its new grammatical meaning, the only one available for the construction."

A further link in this chain of functions involves the extension of complementizer 'say' to the class of evaluative predicates, as well as the verb 'seem'. In both Gbe and the Surinamese Creoles, 'say' introduces extraposed subject complements of predicates like 'true, strange', and emotive predicates like 'be painful', 'be pleasing', etc.

(13) a. SN A tru tak' tamara un no abi fu kon na wroko? 
it true COMP tomorrow we NEG have to come LOC work

'Is it true that tomorrow we do not have to come to work?'

(Sranan-English Online Dictionary, Entry under 'tru')

b. Ewe É-vé-m ná wò bé nè-gblẽ fofo-wò dí.

it-IMPERS-pain-me DAT you COMP you-spoil father-you DIR

'It pains me that you abandoned your father.'

In the Surinamese Creoles, gersi/geli 'seem' governs extraposed sentential subjects, as in the following examples:

(14) SN A gersi taki den kuli wani teki a kondre now op.

It seem COMP DET Hindustanis want take DET country now up

"It seems that the Hindustanis want to take over the country now."

(Winford 2000:96)

Similarly, in Fon, the verbs $q i$ and $c i ́$ 'seem' license an expletive subject, and take an extraposed sentential complement introduced by $d \grave{\jmath}$.

(15) Fon (É) dìlcí dj̀ Koku jè àzòn.

It seem/seem COMP Koku fall sick

'It seems that Koku is sick.' (Lefebvre and Brousseau 2002, ex. 105, p. 276). 
Yet another function of 'say' in the two language groups is to introduce complements to predicates that convey modal notions such as possibility and probability or inferred certainty. In the Surinamese Creoles, expressions such as a kan (de)/sa 'it can be', which indicate possibility, take a taki/táa complement, as in the following examples:

(16) a. SN A kan (de)taki Jan ben sribi kaba.

it can be COMP John PAST sleep COMPL

'It's possible that John was already sleeping.' (Winford 2000: 94)

b. PM A sa de taki a o go a Faansi djonson.

it can be COMP she FUT go LOC France soon

'It's possible that she'll go to France soon.' (Migge 2006: 43)

Similar constructions involving a modal and a copula element (nyî) are found in Gbe languages.

$$
\begin{aligned}
& \text { Waci á tín nyí bá Kōfi dù-nà nú cú sã́. } \\
& \text { It can be COMP Kofi eat-HAB thing all before }
\end{aligned}
$$

'It is possible that Kofi was greedy before.' (Migge 2006: 43)

The Surinamese Creoles also have constructions in which modal expressions like $m u(s u)(d e)$ 'must/should be' and de fanowdu 'be necessary' take a 'say' complements to convey the sense of probability and necessity, respectively.

(18) SN A musu de taki a pikin ben nyan a kuku. 
it must be COMP DET child PAST eat DET cake

'It's probable that the child ate the cake.' (Winford 2000:98)

In the case of Gbe, we only found constructions in which a verb meaning 'be necessary' selects a 'say' complement. Further research is needed on this issue.

(19) Waci ó hyã bó dovi a dó lá kplò xo $a$ a $\quad$ mə.

it need that child DET must FUT sweep room DET in

'It is necessary that the child must clean the house.' (Migge 2006:51)

A final link in the chain of functions involves the use of 'say' to introduce subordinate clauses of purpose and result (or consequence).

(20) a. SN En nownow, efu yu go na wowoyo taki yu e go And now, if you go LOC market say you IMPF go bai wan afu sensi, yu sabi o meni en? buy one half cent, you know how much it?

'Today, if you go to the market to buy a $1 / 2$ cent, do you know how much you have to pay for it?

b. Ewe É-tsó ati bé (né) ye-a-fo-e.

s/he-take stick COMP LINK LOG-SUB-strike-it

'S/he took a stick in order to hit him/her.' (Ameka 2008: 161)

c. Ewe é-dògo bé ye-a-qu nú. 
He-go.out say SRP-SUB-eat thing

'He went out in order to eat.' (Lord 1976:185)

Note that the matrix verbs in these cases are not verbs of complementation. The 'say' clauses are not nominal objects, but have an adverbial function.

In this section we showed that the complementizer taki/táa in the Surinamese Creoles performs the same functions as its counterparts in varieties of Gbe. In both language groups 'say' can function as a quotative and as a complementizer. In the latter function it introduces sentential complements of perception, cognition and utterance verbs, as well as complements of verbs conveying emotive, modal etc. notions. It also introduces subordinate clauses of result and purpose and extraposed sentential subjects. In the following section, we explore the syntactic properties of 'say' complements in Gbe languages and the Surinamese Creoles.

\section{Aspects of the syntax of fact-type complements}

Like other items that have undergone processes of grammaticalization, whether internally or externally motivated, 'say' in Gbe and Surinamese Creoles is a multi-functional item, which belongs to different syntactic categories, and therefore displays a variety of syntactic properties. It turns out that these properties are quite similar (though not identical) across the two language groups. For instance, there are certain constraints on the occurrence of 'say' in its function as complementizer, which the two language groups share. In addition, there are shared constraints on syntactic operations such as extraction and movement, which apply to constructions containing 'say' complements. There are also some relatively minor differences between the two language groups, which we will point out in the course of this discussion. In the remainder of 
this section we discuss and compare the categorical status of 'say' and its distributional properties, as well as the syntactic properties of structures involving quotative and complementizer 'say' in both the Creoles of Suriname and Gbe.

\section{1. The syntax of constructions involving 'say' as a quotative V2}

We have already noted that, when 'say' is used as a main verb it functions as a reduced verb in a great number of Gbe languages and in Saamaka (cf. section 2). We will not discuss this further here, but focus instead on 'say' in its other functions.

The two language groups display similarities in the behavior of 'say' when it is used as a quotative V2 following verba dicendi and other predicates that serve as V1. In this function, it is semantically similar to verbs in that it still expresses a lexical rather than a functional or grammatical content: it denotes the action of speaking. It differs from regular verbs in the Surinamese Creoles and Gbe in that it cannot select its own TMA and Negation specifications (21), nor its own subject argument. These are shared with the main verb in the construction:

(21) a. PM Neen a sisa be begi en (*be) taki 'fon den apodon sii gi mi' then DET sister PAST ask him PAST QUOT crush DET palm.tree nut give me.

b. PM Neen a sisa begi en (*be) taki 'fon apodon sii gi mi'. then DET sister ask him PAST QV crush palm.tree nut give me 'Then the woman asked him politely: 'crush these palm tree nuts for me'.

c. Ewe Wó-le bublu gé dé-e (*a)-bé wò-a-de they-be.at RED-talk_angrily PROSP ALL-him (POT)-say he-POT-remove así le núququ-a пu. 
hand LOC food-DEF skin

'They will ask him angrily to leave the food.' (Essegbey, pc March 2011)

We analyze such constructions as paratactic serial verb constructions consisting of two VPs, headed by a single T(ense) head. In this function, 'say' still retains a verbal function, but in a sense, it is morphologically impoverished, and already on the path toward semantic bleaching and complementizer status.

\section{2. The syntax of constructions involving 'say' as a complementizer}

By contrast, constructions in which 'say' functions as a complementizer must be analyzed as having only one verb that is subcategorized for a complement clause headed by 'say'. Complementizer 'say' in the Surinamese Creoles and Gbe appears to have lost its verbal characteristics, suggesting that even if it started out as a serial verb, which is not accepted by all researchers (Güldemann 2008), it is no longer a V2 in a verbal series. It does not express any lexical content, but simply performs the function of introducing a sentential complement to a variety of different predicates such as utterance verbs, perception and cognitive verbs (cf. Section 3 above). In this function, like quotative 'say', it cannot select a semantically compatible TMA and negation specifications following a V1 and it cannot be predicate clefted (cf. 22).

(22) a. SN * $\underline{\text { Taki }}$ mi sabi taki a pikin de na oso.

$$
\text { say I know say DET child COP LOC house }
$$

'I know that the child is at home.'

b. Aja *mó yi mi jí mo mí á xō nūxū só jakōtōme nyo 
j̄jj̄̄-wo.

say FOC we look for say you FUT speak words of Jakotome story past-PL

'She knows/knew that I'm sick.'

Along similar lines, Lefebvre and Loranger (2008: 1171f) argue that complementizer táa in Saamaka is not fully verbal as it cannot be predicate clefted by all their informants and also cannot be nominalized through reduplication like other verbs in the language. They note also that táa cannot be preceded by TMA markers when it follows another verb, i.e. functions as a V2 (p. 1175). They further argue that similar properties apply to the Fon complementizer $d \grave{j}$ (p. 1185).

Finally, in the Surinamese Creoles and varieties of Gbe complementizer 'say' cannot be stranded, but is simply omitted (23a, c), unlike serial verbs such as gi and its Gbe counterpart $(23 \mathrm{~b}, \mathrm{~d})$. This suggests that in both language groups complementizer 'say' is closely linked to its complement. Note that complementizer that in English shows the same behavior.

(23) a. SN San den taigi yu (*taki)?

what they tell you COMP

'What did they tell you?'

b. PM Sama a lon gi?

person s/he run give

'Who did she run from?'

c. Ewe Nú ka wó-gblo ná wò $\quad(* b e)$ ? 

thing CQ they-say DAT you COMP
'What did they say to you?'
d. Aja Kofi e e sa axwe lo $\underline{\text { no. }}$.
Kofi FOC he sell house DET give
'To Kofi he sold the house.'

There are also marked similarities between the two language groups involving restrictions on the distribution of 'say', as well as various types of movement phenomena in 'say' complements, to which we turn our attention in the following sections.

\section{3. The distribution of complementizer and quotative 'say'}

Previous research on the Surinamese Creoles has shown that the occurrence of complementizer (24a-b) and quotative (24c) taki is subject to some restrictions, which our own data confirm.

Neither can occur immediately following the main verb taki:

(24) a. ND $A$ taki (*taki) a sabi en. she say say she know him

'She said she knows him.'

b. SN A man taki (*taki)a e waka dan a si wan sani tanapu. DET man say say he IMPF walk then he see one thing stand 'The man said he was walking then he saw something standing.'

c. PM Neen a taki (*taki) "Komoto a ini a osu ini." then she say QUOT come.out LOC inside DET house inside 
'Then she said saying 'Get out of the house.'

d. SN Dagu taki (*taki), "No man, mi dati no o slakti mi meti ete." dog say say no man I EMP NEG FUT butcher my animal yet Spider told Dog, "Dog, I'm going to butcher my animal yet."

The case is slightly different in Saamaka which has two verbs meaning 'say', taki and táa. We treat the Saamaka complementizer and quotative táa as a reduced form of taki 'say' (but see Lefebvre and Loranger 2008 for a different view). According to Byrne (1987:147) and Lefebvre and Loranger (2008: 1175ff) and our own data, both taki and táa can be used as main verbs, though táa seems to be functionally reduced as a main verb. While it appears to also be able to take TMA makers (Lefebvre and Loranger 2008: 1175), it typically appears without them when introducing speech, its main function. Verbal táa also cannot subcategorize for complementizer and quotative táa. By contrast, the verb taki in Saamaka obligatorily selects táa to head its complement clause.

(25) a. SM A táa (*táa) di mujée bi gò a di kéiki. he say (COMP) DET woman PAST GO LOC DET church

b. SM A táki *(táa) di mujée bi gò a di kéiki. he say COMP DET woman PAST GO LOC DET church 'He said that the woman had gone to church.' (Byrne 1987:147-148) 
Similar co-occurrence restrictions apply in most varieties of Gbe, where complementizer (26a) and quotative (26b) 'say' cannot immediately follow its homophonous main verbal counterpart, even if 'say' does not appear to be a reduced verb such as in Maxi.

(26) a. Maxié do (*do) mõto o gba.

she say say car DET break

'She said that the car is broken.'

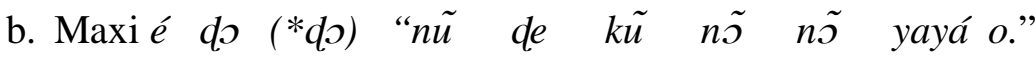

it say say thing DET NEG HAB stay zero NEG

'It is said "nothing is without a purpose".'

Lefebvre and Loranger's (2008: 1186) Fon consultants also reject sentences that exhibit a sequence of two consecutive $d \grave{s}$, like the following:

(27) Fon *kokó djo djo àsíbá yavi.

Koku say say Asiba cry

'Koku said that Asiba cried' (Lefebvre and Loranger 2008:1186)

Either another verb meaning 'to say' is used instead of $d \rho$, bé etc. in the main clause (28a), or in the case of a quotative construction, only one $d o$, bé etc. occurs (28b). 
(28) a. Ewe É bé (*bé): “do afé loo!"

he say say reach home UFP

'Then he said: “welcome.”' (Ameka pc. February, 2011)

b. Ewe É gblo be: “do afé loo!”

he say say reach home UFP

'Then he said: "welcome."”

The only language where this pattern does not appear to apply is Gun, whose speakers, according to Aboh $(2002,2006)$, accept sentences involving a do do sequence.

(29) Gun Àsibá dò dò Kòfí ní jì hàn.

Asiba say say Kofi obl sing song

'Asiba said that Kofi should sing a song.' (Aboh 2006: 25)

The pattern found in most of the Gbe languages (26-28) closely parallels that found in Saamaka where a sequence of táa + táa is not permissible. Either taki is used as the CTP instead of táa (25b) or, in the case of the quotative, táa is employed as the sole predicate (25a). This strongly suggests that the Saamaka pattern arose due to substrate influence from varieties of Gbe.

In Sranan Tongo and the Eastern Maroon varieties, complementizer and quotative taki appear to be obligatory when they are not adjacent to main verb taki.

(30) a. PM Den be taki taa dei taki den o kon.

They PAST say other day say they FUT come 
'The other day they said that they would come.' (PM 3)

b. SN Vooral efu yu srefi taki en taki yu na sarasara.

Particularly if you self say him COMP you COMP shrimp

'Particularly, if you have said so yourself that you're the shrimp.' (SN 8B)

In Saamaka, it is not possible for táa functioning as a CTP to co-occur with complementizer or quotative táa in sequence even if they are not directly adjacent (Lefebvre and Loranger 2008: 1177).

(31) $\mathrm{SM} * a$ táa da mi táa ... he say to me COMP

[lit. 'he said to me that ...] (Lefebvre and Loranger 2008: 1177)

If taki or another verb of saying functions as the CTP, however, then complementizer and quotative táa are obligatory in Saamaka when other material intervenes between them (32).

(32) SM di wenkeman taki oto dia táa mi musu wasi paabi lai. DET shop-owner say other day say I must wash dish load 'The shop-keeper (-owner) said the other day that I have to wash the dishes.'

This pattern again closely resembles that found in the Gbe languages where the verb 'say' and its homophonous complementizer or quotative counterpart cannot co-occur in sequence even when 
they are not directly adjacent. In this case, another verb meaning 'to say', such as taki, is used instead of táa. In these constructions, the quotative or complementizer 'say' are obligatory (33).

$$
\begin{aligned}
& \text { Ewe É-gblo nरe *(bé) (né) wo-a-gé dé kaa lá me. } \\
& \text { he-say DAT:he COMP JUSS he-SUBJ-fall all car DEFinside } \\
& \text { 'He said to him that he should get into the car.' (Ameka 2008:156) }
\end{aligned}
$$

\subsubsection{Optionality of the 'say' complementizer}

There appears to be a difference between the Creoles and Gbe with regard to the optionality of complementizer 'say'. In Pamaka, Ndyuka and Sranan, complementizer presence seems to vary depending on the type of CTP as well as the nature of the complement. For instance, complement clauses of utterance verbs such as taagi 'tell', piki 'answer' seem to nearly always be headed by the complementizer taki when they express a simple proposition. ${ }^{8}$ Absence of the complementizer is also relatively rare in the case of verbs such as sabi 'know' and pakiseli 'think'. By contrast, in the case of verbs such as yee 'hear' and denki 'think' more than half of the instances do not involve the complementizer taki. Finally, verbs like si 'see' select complement clauses with and without taki to roughly the same extent.

(34) a. PM Ma mi yee _ a án bun gi en.

but I hear COMP it NEG good give her.

'But I hear that she does not like it/approve of it.'

\footnotetext{
${ }^{8}$ Due to lack of conversational recordings, we could not investigate this issue for Saamaka.
} 
b. PMWe $m(i)$ be yee taki $B \quad e$ nyam en.

well I PAST hear COMP name IMPF eat it

'Well, I heard that B takes it [cocaine].'

c. SN Ma mi denki mi lobi a kronto orgeade moro.

but I think I love DET coconut drink more

'But I think I love coconut water the best.'

The complementizer is also sometimes absent in Saamaka, but Byrne (1987:148) claims that, according to an informant, complements with a zero complementizer express propositions that are known to be true, while use of táa signifies that the proposition is merely presumed to be true.

(35) a. SM A sabi táa di womi be hondi di pingo. (Byrne 1987:148)

he say COMP DET man PAST hunt DET pig

'He knows (i.e. presumes) that the man had hunted the pig'

b. SM A sabi _ di womi be hondi di pingo.

he say COMP DET man PAST hunt DET pig

'He knew (i.e. is sure) the man had hunted the pig.'

We found no evidence of such a distinction in Sranan Tongo or the Eastern Maroon Creoles. In varieties of Gbe, by contrast, the complementizer must be present in all of the contexts discussed above. 
(36) a. Waci en nyə mə nyá bə mi lo əфla yi wa a.

yes I NEG know COMP you LOC name go do NEG

'Yes, I did not know that you are going to Grand Popo.'

b. Maxié ká nã se do ehi j̀ ehi do xlohlo le a.

we ? FUT hear COMP you TOP you have power such NEG

'We will also hear that as for you, you do not have such power.'

c. Xwlamì ún ká xòsè bé sójà wè.

you NEG ? believe COMP soldier FOC

'Don't believe that he is a soldier.'

In Ewe the complementizer can only be absent following the causative verb $n a$.

(37) a. Ewe vu.sogbo.do

ná — me-tsri aha.

blood.become_plenty.illness GIVE COMP I-hate alcohol

'High blood pressure made me avoid alcohol.'

b. Ewe É-ná (bé) me-tsí megbé.

it-give COMP I-stay behind

'It made me stay behind.' (Felix Ameka, pc. February 2010)

\subsection{Extraction out of 'say' complements}


In both language groups, wh-extraction out of a 'say' complement is possible. In some Gbe languages a co-referential pronoun is left in the place from which the NP was extracted (38b), while in other cases this is not necessary (39c).

(38) a. PM Ondi sama den taygi en taki _ dede? which person they tell him COMP dead 'Who did they tell him is dead?' (M. Sanna, pc. March 2010)

b. Ewe Ame ka-é wó-gblo nê bé é-ku? person $_{i}$ CQ-FOC they-say DAT:he ${ }_{j}$ COMP he $\mathrm{i}_{\mathrm{i}}$-die 'Who did they tell him is dead?' (Ameka pc, May 2010)

c. Gun Été!i wé à kànbio! djo Kòfi xò $t_{i}$. what FOC you ask that Kofi buy 'What did you ask that Kofi buy?' (Aboh 2006: 42)

The two language groups also display similarities involving focusing of constituents from the ‘say’ complement. Aboh (2006) discusses such similarities between Saamaka and Gun. In one type of focus, the focused category (in brackets) appears between complementizer 'say' and the complement clause subject.

(39) a. SM A sábi táa [dipingo]i di wómi bi hondi ti. s/he know COMP DET pig DET man PAST hunt '(S)he knows that the man hunted THE PIG' (Byrne 1987:149) 
b. Gun Ùn kànbio dj̀ [ménù] wè xò wémà lo?

I ask that who FOC buy book DET

'I asked who bought the book.' (Aboh 2006:42)

Note that, in both languages, the moved element may not immediately precede the complementizer,

(40) SM *A taki [a di keiki] táa di mujee bi go.

3sg say LOC DET church COMP DET woman PAST go

'(S)he said that the woman went TO THE CHURCH.' (Byrne 1987:150)

At the same time, according to Aboh, both complementizers $d \jmath$ and táa also allow for long extraction across an embedded focus- or wh-phrase.

(41) a. SM [Diwómi]i (hen) a sabi táa $\mathrm{t}_{\mathrm{i}}$ bi hondi di pingo.

DET man he.EMP he know that PAST hunt DET pig

'It's the man that he knows had hunted the pig'. (Byrne 1987:149)

b. Gun Été!i wé à kànbio! đjo Kòfi $x \grave{\jmath} t_{i}$.

what FOC you ask that Kofi buy

'What did you ask that Kofi buy?' (Aboh 2006: 42) 
These and other data lead Aboh to conclude that the structure underlying 'say' complements in Saamaka and Gun is identical. In both cases, the 'say' complementizer heads ForceP and marks the embedded clause as an argument of the matrix verb (Aboh 2006:33). Indeed, he argues on the basis of a comparison of the 'say' complementizers with the irrealis complementizers nú/ní (Gun) and $f u$ (SM), that the entire structure of the left periphery is more or less identical in the two languages. Lefebvre and Loranger (2008:1185) point out that Aboh's analysis can be carried over to Fon in a straightforward way, and add:

With Aboh (2002:7), we conclude that the Gungbe/Fongbe and the SA [Saamaka] complementizer systems parallel one another, $[\ldots]$, and that the striking similarities between the two "cannot be accidental or regarded as the manifestation of some unmarked feature of UG."

\subsection{Raising phenomena}

A final point of comparison between Gbe and the Surinamese Creoles involves the raising-tosubject of complements to evaluative, modal and similar predicates. In both language groups, such complements normally appear in extraposed position.

(42) a. SN A tru taki Marinus lobi Margie.

it true COMP name love name

'It is true that Marinus loves Margie.'

b. Xwla É nyo! bé yè ún lé ká nò xwé cán.

it be.good COMP him NEG IMPF want stay house even 
'It is good that he does not even want to stay at home.'

c. Ewe É-vé-m ná wò bé nè-gblẽ fofo-wò dí.

it-impress-pain-me DAT you COMP you-spoil father-your DIR

'It pains me for you that you abandoned your father.'

It appears that, for some speakers at least, such complements can be raised to subject position in Gbe varieties like Ewe and Gun, similarly to that-headed complements in English. In Ewe, such subject complements are marked by the background topic marker, but no anaphoric pronominal appears in the rest of the clause, as is typical in topicalized structures. Hence it would appear that they are treated as subjects (Ameka, pc 2010).

(43) a. Ewe Bé wó-vá lá nyó.

COMP they-come TP become.good

'That they came is good.'

b. Ewe Bé wó-gbé wó-noewó lá nyé nyatefé.

COMP they-refuse they-RECIP TP COP truth

'That they divorced each other is true.' (Ameka, pc February 2010)

According to Aboh (2006:27), Gun also allows raising of 'say' complements to subject.

(44) Gun do yokpo le ná hon yi mon íyà yéton that children NUMB FUT flee go see mother 3PL-Poss 


$\begin{array}{lllll}n i & \text { má } & \text { kpácá dó wè kpálikpálí blò. } \\ \text { MOD NEG } & \text { surprise at } & \text { 2SG-ACC at all } & \text { not }\end{array}$

'That the children would run (away) to their mother should not surprise you' (Aboh 2006:27)

It's not clear whether this construction is a recent development, or how productive and acceptable it is among speakers of Gbe. Ameka (pc February, 2010) suggests that this may be a newer pattern in Ewe which probably emerged due to calquing on the English construction. Further investigation is needed.

With regard to the Surinamese Creoles, Sebba (1987:78) claims that his Sranan Tongo informants accepted sentences like the following:

SN Taki Kofi no kiri Amba meki wi breyti.
That Kofi NEG kill Amba make we happy
'That Kofi didn't kill Amba made us happy'

Sebba uses this as evidence that Sranan taki has entirely lost its verbal properties and been completely reanalyzed as a complementizer, equivalent to English that. None of our Sranan Tongo or Eastern Maroon informants considered such structures to be acceptable.

In other New World creoles, raising of 'say' complements to subject is disallowed (Winford 1993:295). Nylander (1985) points out that this is also true of Krio, and uses this as evidence that complementizer 'say', at least in that creole, still preserves some verbal characteristics. However, the inability of 'say' to introduce subject complements in these creoles does not necessarily 
negate its status as a complementizer, since this property may not be a universal diagnostic of complementizer status. There is need for formal comparison between 'say' and other complementizers in Gbe and creoles to resolve this question.

Unlike complements to evaluative verbs, complements to the verb meaning 'seem', gersi in Sranan Tongo, geli in the Eastern Maroon Creoles, are always realized as extraposed sentential subjects in the Surinamese Creoles:

(46)
a. SN A gersi taki den kuli
wani teki a kondre now op.
it seem COMP DET Hindustanis want take the country now up
'It seems that the Hindustanis want to take over the country now.'

(Winford 2000:96)

b. PM A geli enkeltaki a konde o seeka nownow de.

it seem like/COMP DET country FUT repair now there

'It seems as if/that the country will be improving now.'

c. PM *A konde geli seeka nownow de.

DET country seem repair now there

Similarly, in Fon, the verbs $q \grave{i}$ and $c i$ 'seem' license an expletive subject, and take an extraposed sentential complement introduced by $d j$.

(47) Fon

(E) $d \grave{l} / c i ́ \quad d \grave{o} \quad k \supset k u \quad j \varepsilon$ àzon.

it seem/seem COMP Koku fall sick

'It seems that Koku is sick.' (Lefebvre and Brousseau 2002: 276). 
The expletive subject is optional in these cases. Note that like their Surinamese counterparts, gersi and geli, the Fon verbs $q i$ and cí mean both 'seem' and 'resemble.'

In Ewe and some other varieties of Gbe such as Gen and Xwla, the words that are used as matrix 'seem' verbs are wo 'do, make' and dzé 'appear'. The complement clauses of these verbs are not introduced by bé but by abé which is a combination of the Potential marker $a+$ the complementizer bé. Abé is also used to express the semblative (Ameka, pc February, 2010). Note that unlike Fon, the expletive is not optional.

(48) a. Ewe É-wo abé Koku le lo lé-m.

it-IMPERS-do COMP.as Koku be.at:PRES sickness catch-PROG

'It seems that Koku is sick.' (Ameka, pc 2010)

b. Ewe É-dzé abé tsi le dza-dza gé.

it-IMPERS COMP.as water be.at:PRES RED-drip PROSP

'It appears that it is going to rain.

c. Xwlaé wà bé gblé é gblé lé són-nú qú gble é gble.

it do COMP spoil it spoil IMPF go-?to but spoil it spoil

lé són-nú. (Xwla 2)

IMPF go-?to

'It seems that the situation is spoiled!' 
According to Ameka (pc 2010), subject raising is possible in these constructions in Ewe. However, there is a semantic difference between the expletive subject construction and the 'raised subject' construction. The latter gives a 'pretend' interpretation and not a 'seem' reading, compare:
a. Ewe É-wo
/dzé abé
Kofi li
Abla.
it-IMPERS-do /appear COMP.as Kofi love Amba

'It seems that /looks like Kofi loves Abla'/ 'It looks like Kofi loves Abla.'

b. Ewe Kofi wo abé

é-l̃ $\quad$ Abla /*dzé.

Kofi do COMP.as 3sg-love A.

'Kofi pretends that he loves Abla.'

Further research is necessary to determine whether all Gbe languages behave similarly in this respect.

\section{Summary of Findings}

The aim of this paper was to compare fact-type complements in the Surinamese Creoles and Gbe in order to determine the relative influence of the latter languages, which functioned as the main input languages to the creation of the Creoles of Suriname, on the former. Our study revealed many close similarities between fact-type complements in the Surinamese Creoles and Gbe varieties and only minor differences between them suggesting that they are closely related (see Table 2). Fact-type complements in both language groups are typically headed by an element 
which is (Surinamese Creoles, and some Gbe varieties) and used to be (in Gen, Ewe) homophonous with a main verb. In the Surinamese Creoles and some Gbe varieties, this element has been bleached of its verbal properties to varying degrees. Fact-type complements in both languages are also selected by the same range of verbs or complement-taking predicates (CTPs). These include utterance verbs such as verbs of speaking, asking and promising, perceptionexpressing predicates such as 'see', 'hear', 'smell', and cognition-expressing verbs such as verbs of thinking and knowing. Fact-type complements are also selected by other kinds of verbs such as desiderative verbs, emotion-denoting verbs, evaluative predicates such as 'good', 'true', and causative verbs. In addition, they function as complements to the equivalents of the verb 'seem' in both Gbe varieties and the Surinamese Creoles. In this case, they have the function of extraposed subjects. Finally, 'say'-headed phrases in Gbe and the Surinamese Creoles also introduce subordinate clauses of purpose and result.

With respect to their structure, fact-type complements in the Gbe varieties appear to be obligatorily headed by the complementizer 'say' when they are selected by these verbs. In the Surinamese Creoles, a few restrictions appear to apply. First, the verb taki in Sranan and the Eastern Maroon Creoles cannot select complements headed by taki when they are directly adjacent. In Saamaka, the predicate táa cannot select táa-headed complements even if they are non-adjacent. Second, in Sranan and the Eastern Maroon Creoles, the presence of complementizer taki is not obligatory with some verbs such as 'hear', 'see' and 'think', for instance. This variability does not appear to be related to differences in meaning, though.

Constructions in which 'say' functions as a complementizer are best analyzed as structures which involve a main verb that is subcategorized for a sentential complement headed by the complementizer 'say' in both the Creoles and Gbe varieties. In these constructions, 
complementizer 'say' is semantically bleached and does not have verbal characteristics in that it cannot select TMA specifications or be predicate clefted. Finally, fact-type complements in Gbe and the Creoles of Suriname also behave similarly with respect to extraction phenomena. In both language groups wh-extraction is possible and focused elements can only appear between the complementizer and complement clause. In both language groups, the complementizer 'say' may not be stranded, just like complementizer that in English. In terms of raising phenomena, the Creoles and Gbe are similar in that complements of evaluative verbs and complements of 'seem' are always realized as extraposed subjects. Unlike Gbe, taki/táa-headed complements cannot function as subjects in the Creoles, at least according to our data and informants.

In addition to its complementizer function, 'say' also performs the function of quotative either as a main verb or as a V2 following an utterance predicate in both language groups. As a quotative 'say' is generally not modified by TMA markers - though it can be modified by some (e.g. the future or potential element $(n / l) a)$ when it stands on its own - and introduces direct and indirect speech of verba dicendi other than the verb taki/táa. When it is preceded by an utterance verb, such constructions are best analyzed as paratactic constructions in which the TMA specifications of the utterance verb have scope over taki/táa. In the next section we discuss the implications of these findings.

Table 2: Similarities between fact-type complements in the Creoles of Suriname and Gbe

\begin{tabular}{|l|l|l|}
\hline Characteristics & Suriname Creoles & Gbe varieties \\
\hline Head of fact-type complements is homophonous & yes & yes (in case of some varieties; \\
with verb 'say' & & used to be in case of others) \\
\hline Complementizer 'say' is semantically bleached & yes & yes \\
\hline
\end{tabular}




\begin{tabular}{|c|c|c|}
\hline $\begin{array}{l}\text { Complementizer 'say' cannot select TMA } \\
\text { markers \& be predicate clefted }\end{array}$ & yes & yes \\
\hline Complementizer 'say' cannot be stranded & yes & yes \\
\hline $\begin{array}{l}\text { Complementizer 'say'-headed complements } \\
\text { cannot function as subjects }\end{array}$ & yes & no \\
\hline $\begin{array}{l}\text { Extraction out of fact-type complements is } \\
\text { possible }\end{array}$ & yes & yes \\
\hline $\begin{array}{l}\text { Complements of 'seem' and evaluative verbs } \\
\text { always appear as extraposed subjects }\end{array}$ & yes & yes \\
\hline $\begin{array}{l}\text { A similar wide range of CTPs e.g. utterance, } \\
\text { perception, cognition, desiderative, evaluative, } \\
\text { causative verbs etc }\end{array}$ & yes & yes \\
\hline complementizer 'say' is obligatory & $\begin{array}{l}\text { Yes (expect for a few } \\
\text { verbs) }\end{array}$ & yes \\
\hline $\begin{array}{l}\text { complementizer 'say' may directly follow } \\
\text { homophonous verb 'say' }\end{array}$ & no & $\begin{array}{l}\text { no (except for some varieties } \\
\text { in which homophonous 'say' } \\
\text { retains a verbal function, e.g. } \\
\text { Gun) }\end{array}$ \\
\hline $\begin{array}{l}\text { complementizer 'say' may follow homophonous } \\
\text { verb 'say' if there is intervening material } \\
\text { between the two }\end{array}$ & yes & $\begin{array}{l}\text { yes (in case of some varieties } \\
\text { where 'say' is verbal) }\end{array}$ \\
\hline $\begin{array}{l}\text { complementizer 'say' introduces extraposed } \\
\text { subjects }\end{array}$ & yes & yes \\
\hline complementizer 'say' introduces clauses of & yes & yes \\
\hline
\end{tabular}




\begin{tabular}{|l|l|l|}
\hline purpose and result & & \\
\hline 'say' functions as a quotative by itself and & yes & yes \\
following another main verb & & \\
\hline
\end{tabular}

\section{Discussion}

The range of functions performed by 'say' in the Gbe languages and the Surinamese Creoles and the structural characteristics of 'say'-headed phrases bear striking resemblance to so-called 'grammaticalization chains' that link the various functions of 'say' in many other languages. In the literature on African languages, including varieties of Gbe, it has indeed been argued convincingly that such functions developed gradually due to processes of internally-motivated grammaticalization (Lord 1993; Heine et al 1991). However, sociohistorical and linguistic evidence suggest that a similar grammaticalization account is not feasible in the case of the Creoles of Suriname. As convincingly argued by Bruyn (1996), the properties of taki/táa in the Creoles of Suriname are best analyzed as a case of contact-induced change. Below we first discuss the grammaticalization of 'say' complementizers which we feel accounts well for the functions and distributions of 'say' in Gbe varieties. In a second part, we discuss the emergence of taki/táa in the Creoles of Suriname.

\section{1. The grammaticalization of 'say' complementizers}

Typological research has shown that the reanalysis of a speech act verb 'say' and its grammaticalization into a complementizer have occurred more widely than previously thought, for example in Austronesian languages (Klamer 2000), Sinitic languages (Chappell 2008), and 
Caucasian languages (Frajzyngier 1991:226). As Chappell (2008:48) notes, "the SAY grammaticalization pathway for complementizers is thus spread across several continents and many language families." However, the grammaticalization paths that 'say' verbs have followed are far from identical across the languages concerned. One does indeed find a number of core functions that seem to be common across these languages, including use of 'say' as a quotative marker, complementizer, marker of embedded questions, and a conjunction introducing purpose or reason clauses (Chappell 2008:49). These core functions, are, as we have seen, also found in Gbe and the Surinamese Creoles. However, 'say' performs many other functions in other languages, which are not found in Gbe or the Surinamese Creoles. These include uses as a hearsay marker of evidentiality, comparative marker, ${ }^{9}$ mirative marker, topic marker, and various others (see Chappell 2008:49 for a more extensive list). ${ }^{10}$ The fact that the Surinamese Creoles and Gbe languages share the same range of functions of 'say' is therefore important evidence in favor of their relatedness. We take this to suggest that the properties of 'say' and 'say-headed

${ }^{9}$ The element abé in Ewe functions as a semblative rather than as a marker of comparison in the strict technical sense of the term as can be seen in the following example:

É vivi abé sukli.

It sweet resemble sugar

'It is as sweet as sugar.'

${ }^{10}$ Felix Ameka (pc 2011) informs us that bé and similar forms in languages like Ga and Akan enter into construction with a 3PL pronoun and are used to introduce rumors etc which has the flavor of a hearsay function. However, in this use, be does not appear to be an evidential marker as such but it does have s similar function. 
phrases in the Surinamese Creoles most likely emerged due to substrate influence from Gbe (see below).

The core functions of 'say' are cross-linguistically linked to each other in a common grammaticalization pathway. Chappell (2008:50) represents this pathway as follows, for Sinitic languages:

(50) SAY > quotative function as main verb of principal clause, introducing direct or indirect speech.

$>$ quotative function as V2 in a serial verb construction where $\mathrm{V} 1=$ speech act verb. >complementizer upon extension of V1 to other verb classes including cognition, perception, emotion and modal.

The Gbe languages and Surinamese Creoles take this pathway further, by extending the functions of 'say' to that of subordinator introducing clauses of purpose and consequence. It has been claimed that, corresponding to this grammaticalization path, there is an implicational hierarchy of verb classes that can occur with 'say' complementizers crosslinguistically. ${ }^{11}$ Chappell (2008:54) represents this as follows:

(51) (i) factive verbs in general > (ii) modal verbs > (iii) stative and emotion verbs > (iv) cognition and perception verbs $>$ (v) speech act verbs.

\footnotetext{
${ }^{11}$ See Güldemann (2008) for a view that challenges claims about the extended quotative complex as described in previous literature on the grammaticalization of 'say'in West African languages.
} 
In Gbe and the Surinamese Creoles, 'say' is used with all verb classes up to and including modals (see Heine et al 1991; Saxena 1995). Again, this similarity seems to support our claim for Gbe influence on the use of taki/táa in the Surinamese Creoles. In addition, Saxena (1995:351) argues that the grammaticalized functions of 'say' follow a strict unidirectional path with respect to the types of verbs with which it is used. This results in a progression that yields an implicational hierarchy of possible grammaticalizations, as follows:

$$
\begin{aligned}
& \{\text { direct quote }>\text { 'say' > 'know' > 'believe' > 'want' > purpose and/or reason } \\
& >\text { conditional > comparative marker }\}
\end{aligned}
$$

Based on his own detailed cross-linguistic study, Güldemann observes that "the two grammatical sequences \{quotative > complementizer > other $\}$ and $\{$ 'say' > 'know' > 'believe' > 'want' etc \}, which are claimed by the authors of the extended quotative complex to instantiate a necessary implicational hierarchy in the development of function words, are not universal" (2008:458). We acknowledge this, and make no claims here about an implicational hierarchy in the grammaticalization of the functions of 'say'.

Finally, it is to be noted that, synchronically, 'say' in Gbe languages and the Surinamese Creoles remains a multifunctional item that belongs to different lexical and functional classes. This synchronic pattern presumably preserves the various stages of the grammaticalization path that 'say' followed, at least in Gbe. Such patterns are typical of other grammaticalized items as well (Klamer 2000:71). In some cases, the relevant item undergoes so much 'semantic bleaching' that it loses much of its previous lexical character. This seems to have happened to 
some extent to Ewe bé, which seems to have more limited verbal functions, having been replaced in many uses by gblo 'say', as we saw earlier. ${ }^{12}$ Saamaka complementizer táa may well be on a similar path, though it still competes with taki in its main verbal function.

\section{2. The grammaticalization of taki.}

We now turn our attention to the process by which taki/táa was reanalyzed from main verb to multi-purpose complementizer in the Surinamese Creoles. There is some evidence from the early Sranan texts that this may have begun in the $18^{\text {th }}$ century, and then developed more rapidly in the course of the first half of the $19^{\text {th }}$ century. Plag (1995) found one example of complementizer taki in van Dyk's (1765) text, where it is used after sabi 'know'.

(53) ESN Oenno zabi takki no wan zomma ben pree lange da drom
you know say no one person PAST play with DET drum
na negi moen ten.
in nine month time

\footnotetext{
${ }^{12}$ In this regard, we differ from Güldemann (2008:347), who suggests that bé was originally a marker conveying similarity or manner or perhaps a type of equational verb, which was later grammaticalized into a complementizer. Felix Ameka (pc 2010) points out that the be form in constructions with the potential marker is what has grammaticalised into a semblative marker, not the other way around. There is another quotative marker álé 'thus', which is linked to the kind of source that Güldeman postulates.
} 
'You know that no one has been playing on that drum for nine months.'

(van Dyk 1765:108, quoted by Plag 1995:121)

Plag acknowledges that this single use of complementizer taki is somewhat unexpected, since 36 of the 38 complement clauses found in van Dyk's texts are asyndetically connected to the matrix clause. The other exception involves use of complementizer dat, which Plag treats as a borrowing from Dutch (1995:121). In addition, Plag notes that van Dyk's texts contain no examples of the use of taki as a quotative. This use, however, is found in Schumann's (1781) bible translation, after verba dicendi such as piki 'answer', haksi 'ask', etc. (Plag 1995:122). Once more, complement clauses to speech act, cognition and perception verbs are asyndetically connected to the matrix clause. Plag therefore suggests that, "in the $18^{\text {th }}$ century, the grammaticalization of taki as a complementizer was still at an early stage" (1995:123). By contrast, he points out that texts of the late $18^{\text {th }}$ to mid $19^{\text {th }}$ centuries contain increasingly frequent occurrences of taki as complementizer, though instances of asyndetic complementation as well as use of complementizer dati are also found. ${ }^{13}$ Plag concludes that, by the middle of the $19^{\text {th }}$ century, "Taki is firmly established as a complementizer, but it is not yet used in adverbial clauses nor in subject clauses" (p. 130).

It seems highly unlikely that taki could have developed this range of functions so quickly as a result of spontaneous (internally motivated) grammaticalization. Such processes usually take a

\footnotetext{
${ }^{13}$ Plag $(1995: 135)$ claims that the establishment of dati as a complementizer was an innovation of the late $19^{\text {th }}$ century, and argues that this occurs only after the establishment of complementizer taki, as a result of Dutch influence. See Plag (1993:79-83) for further details.
} 
long time to develop and to become conventionalized. Yet the grammaticalization of taki appears to have occurred within a very short period, according to the historical records. Such a scenario is more in keeping with processes of contact-induced change under conditions of language shift, i.e. natural second language acquisition, which occur with far greater speed. It therefore seems highly likely that substrate influence from Gbe and other West African languages played a key role in the emergence of the various functions of taki. Such influence may have begun as early as the formative period of Sranan in the late $17^{\text {th }}$ to early $18^{\text {th }}$ centuries, and continued throughout the $18^{\text {th }}$ and $19^{\text {th }}$ centuries as newly arrived Africans continued to learn the existing varieties of the Surinamese plantation creole. Plag (1995:136) suggests that "the period in which taki emerges as a complementizer - which lasts from the end of the $18^{\text {th }}$ to the middle of the $19^{\text {th }}$ century - can be characterized sociolinguistically as a time when large numbers of speakers of African languages shift from their mother tongues to Sranan.” But similar scenarios of second language acquisition were true of the entire $18^{\text {th }}$ century, including the period when Gbe languages were the dominant substrate input (Arends 1995). At the same time, it is reasonable to assume that other West African languages that were present in the early period, including Akan, also played a role in the multifunctional use of taki. Indeed, Akan complementizers $s \varepsilon / d \varepsilon$, which apparently originated in a verb meaning 'say', display a range of complementizer functions that is almost identical to that of 'say' in Gbe and Surinamese Creoles (see Boadi 2005, Chapter 2 and Osam 1996, 1998 for further details). ${ }^{14}$

\footnotetext{
${ }^{14}$ There are a number of similarities between 'say' complements in varieties of Akan and those in Gbe and the Surinamese Creoles. First, the list of complement-taking predicates in the Akyem variety of Akan provided by Boadi (2005: 54-58) is very similar to that given in Table 1 for Gbe,
} 
Given the paucity of historical texts from earlier periods, one cannot dismiss the possibility that taki was already assuming complementizer functions long before the late $18^{\text {th }}$ century. The single use of complementizer taki in van Dyk's text, quoted earlier, seems to support this view. It should also be noted that the variety represented in van Dyk is probably bakratongo, the variety of Sranan spoken by Europeans or others who were Dutch dominant. This might explain the rarity of taki, and the preference for Dutch dati in these texts. By this interpretation, the sudden appearance of comp taki is due to contact-induced influence from the (field)slave variety on the European variety. According to van den Berg's (2007:317-318) research on the early sources for Sranan Tongo this alternation between complementizers taki and dat(i) has a long history in Sranan Tongo as it is already found in texts dating just after the middle of the $18^{\text {th }}$ century such as the Saamaka peace treaty (1762) and Court Records (1766). Van den Berg (2007:317) goes on to suggest that the two complementizers probably belong to two different $18^{\text {th }}$ century varieties of Early Sranan Tongo; dati probably belonged to varieties of Sranan Tongo spoken by Europeans or those close to them (bakra nengre) while taki was part of varieties associated with the field slaves. However, further research on early varieties of Sranan Tongo is needed in order

English and the Creoles of Suriname. Second, Osam (1994, 1996a) shows that complementizer $d \varepsilon$ in Fante varieties of Akan (corresponding to $s \varepsilon$ in the Twi varieties) also originates from a verb meaning 'say'. Third, according to Boadi (2005:58) predicates such as hia 'be necessary', $s \varepsilon$ 'be inevitable', and tumi 'be possible' also take complements introduced by $s \varepsilon$ in the Akyem (Twi) variety of Akan. Osam (1998:24) points out that predicates like hia 'be necessary' take complements introduced by $d \varepsilon$ (the counterpart of $s \varepsilon$ ) in the Fante varieties of Akan. Finally, Boadi 2005:65) provides examples of $s \varepsilon$ clauses that function as purpose clauses. 
to confirm this. At any rate, the facts we have presented suggest that an explanation of the reanalysis of taki as a complementizer in terms of contact-induced change seems apt.

Various hypotheses have been proposed to account for the mechanism underlying the role of substrate influence in shaping creole grammar. For instance, Heine \& Kuteva appeal to the notion of "contact-induced grammaticalization" and suggest that the emergence of complementizer 'say' could be explained as an instance of what they refer to as 'replica grammaticalization'. This is a process in which "the model language provides a model for both a category and the way that category is replicated" (Heine and Kuteva 2005:80). This involves the following steps:

(54) Replica grammaticalization

a. Speakers notice that in language $\mathrm{M}$ there is a grammatical category Mx.

b. They create an equivalent category $\mathrm{Rx}$ in language $\mathrm{R}$ on the basis of the use patterns available in $\mathrm{R}$.

c. To this end, they replicate a grammaticalization process they assume to have taken place in language $\mathrm{M}$, using an analogical formula of the kind: [My > $\mathrm{Mx}]:[\mathrm{Ry}>\mathrm{Rx}]$.

d. They grammaticalize Ry to Rx. (Heine and Kuteva 2005:92).

Heine and Kuteva rightly reject the viability of step (c) of this process, as it implies that speakers replicate a historical process that took place much earlier, and over a long period, in the model language. Moreover, "there is virtually no information on what conceptual cues speakers may have to reconstruct a process presumed to have taken place in the model language" (2005:92). A 
more likely explanation is that speakers employ analogical inferencing to associate the functions of the model language category with some equivalent item in the replica language. Thus, items like $d \grave{j}$ and bé 'say', are identified with items like taki, and the various functions of the former are 'transferred' to the latter via analogy. This simultaneous transfer of different functions led Bruyn (2008:404) to suggest that the grammaticalization of taki might be better viewed as a case of what Heine and Kuteva refer to as 'polysemy copying', in which "speakers of the replica language.....appear to have used a shortcut by simply copying the initial and the final stages of the process [of grammaticalization]" (2003:555).

Lefebvre \& Loranger (2008) argue that the properties of táa and taki in Saamaka (SA) were derived through relexification - a process that "consists in assigning a new label to an existing lexical entry" (2008:1167). More specifically, they suggest that, "while táa and taki derive their label from English, their semantic and syntactic properties are derived from those of corresponding lexical items in the SA substrate languages", particularly Fon (p. 1170). While we agree with Lefebvre and Loranger (2008) that the properties of the fact-type complements in the Creoles are very similar to those in Gbe, we argue that a relexification account of the origin of these structures is too strong to properly account for the observed similarities. First, although there are close similarities between the two language groups, there are also differences in syntactic behavior. These differences such as the use of fact-type complements in subject position and the optionality of the complementizer in some contexts in the Surinamese Creoles cannot be accounted for using a lexical copying approach. Second, our discussion also suggests that there is variation with respect to the realization of fact-type complementation in both language groups. Since it cannot be assumed that this variation emerged recently, we have to assume that different kinds of models were available from the beginning and that the systems 
found in the Creoles of Suriname are a kind of compromise between them, rather than a direct copy of any of them. Other scholars have also questioned the relexification hypothesis's (RH) strong claim of identity between creole and substrate grammars, while others have expressed concern that it ignores the contribution made by superstrate languages to many cases of creole formation. We think such criticism is justified, but there are certain aspects of the RH which seem quite useful. For instance, the RH recognizes that creole formation involved a type of second language acquisition, and that "in creole genesis, the process of relexification is used by speakers of the substratum languages as a tool for acquiring a second language" (Lefebvre 2001:375). This brings the RH in line with the views of creolists who appeal to the SLA notion of "transfer" as a strategy of restructuring in creole formation (see Siegel 2008). In addition, the suggestion that creole lexical entries were modeled on lemmas that were partly substrate-derived and labeled with superstrate lexemes is reminiscent of similar suggestions about how learners appeal to L1 knowledge in the course of second language acquisition. It has been shown that, in the early stages of SLA, learners acquire L2 lexemes without acquiring their full lemmas. As Pienemann (1998:76) points out:

[...] the L2 learner is initially unable to deposit information into syntactic procedures, because (1) the lexicon is not fully annotated and more importantly (2) because even if the L1 annotation was transferred, the syntactic procedures have not specialized to hold the specific L2 grammatical information.

We suggest that similar restrictions applied to the creators of creoles, who had limited access to native varieties of the superstrate, and therefore limited access to all the input they needed to reconstruct the lemmas associated with the superstrate lexemes they had acquired, and thereby process and produce superstrate structures accurately. Consequently, they fell back on the 
lemmas associated with equivalent items in their L1s, to supply the information necessary for them to initiate more complex syntactic procedures in the emerging creole. However, this still does not fully explain precisely how the properties of substrate lexical items get transferred to superstrate lexemes. To account for this, we appeal to van Coetsem's $(1988,2000)$ notion of imposition - a mechanism in which various properties of a linguistically dominant source language (SL) are transferred to a recipient language (RL) in which the speaker is less dominant, i.e. proficient. Such transfer typically takes place during language production, when speakers are attempting to produce utterances in the less dominant language. The advantage of van Coetsem's model is that it views the mechanisms of change as essentially psycholinguistic in nature, with the individual speaker's agency central to the creation of innovations in the less dominant language. The process itself, then, can be explained in terms of psycholinguistic models of language production (see Winford to appear). From the perspective of such models, imposition simply involves speakers employing the grammatical or phonological encoding procedures of their dominant language in producing the less dominant one. Such processes are instantaneous, in a sense, and their cumulative application by speakers of similar language backgrounds leads eventually to entrenchment and conventionalization of the innovations that are created. Since creole creators simply impose their already operational L1 production procedures on the nascent creole, it is not surprising that the "innovations" they introduce into their L2 variety of the superstrate appear rapidly, and may involve the "transfer" of several syntactic properties simultaneously, as presumably happened in the transfer of the multifunctionality of Gbe 'say' to taki and táa in the Surinamese creoles. An analysis in terms of imposition has the advantage of accounting for notions like "transfer" and "relexification" in terms of psycholinguistic processes of language production, as well as recognizing that the mechanisms at work in creole formation 
are similar to those that operate in various other kinds of bilingual language production (Winford 2008).

\section{References}

Aboh, E., 2006. Complementation in Saramaccan and Gungbe: The case of C-type modal particles. Natural Language and Linguistic Theory 24.1, 1-55.

Aboh, E. 2002. Morphosyntax of the left periphery in Saramaccan and Gbe. Paper presented at the Conference of the Society for Pidgin and Creole Linguistics (SPCL), SanFrancisco.

Ameka, F. K., 2008. Aspect and modality in Ewe: A survey. In: Ameka F. K., Kropp Dakubu, M. E. (Eds.), Aspect and modality in Kwa languages. John Benjamins, Amsterdam, pp. $135-194$.

Ameka, F. K., 2005. Direct and indirect speech in Ewe. Paper presented at a workshop on direct and indirect speech: a crosslinguistic typology at the Research Centre for Linguistic Typology, La Trobe University, Melbourne, June 29.

Arends, J., 1995. Demographic factors in the formation of Sranan. In: Arends, J. (Ed.), The early stages of creolization. John Benjamins, Amsterdam, pp. 233-285.

Bickerton, D., 1984. The language bioprogram hypothesis. The Behavioral and Brain Sciences 7 , $173-88$

Bruyn, A., 2008. Grammaticalization in pidgins and creoles. In: Kouwenberg, S., Singler, A. (Eds.), The Handbook of Pidgin and Creole Studies. Wiley-Blackwell, Oxford, pp. 385410. 
Bruyn, A., 1996. On identifying instances of grammaticalization in creole languages. In: Baker, P., Anand S. (Eds.), Changing meanings, changing functions: Papers related to grammaticalization in contact languages. University of Westminster Press, London, pp. $29-46$.

Byrne, F., 1987. Grammatical relations in a radical creole, John Benjamins, Amsterdam.

Boadi, L.A., 2005. Three major syntactic structures in Akan: Interrogatives, complementation and relativization. Black Mask Ltd, Accra.

Chappell, H., 2008. Variation in the grammaticalization of complementizers from verba dicendi in Sinitic languages, Linguistic Typology 12, 45-98.

Damonte, F., 2002. The complementizer layer in Saramaccan. In: Leonetti, M., Fernandez Soriano. O., Escandell Vidal, V. (Eds.), Current issues in generative grammar: $10^{\text {th }}$ colloquium on generative grammar, Selected Papers, Universidad de Alcalá: Alcalá de Henares, pp. 31-50.

Dixon, R.M.W., 2006. Complement clauses and complementation strategies in typological perspective. In: Dixon, R.M.W, Aikenvald, A. (Eds.), Complementation - A crosslinguistic typology.Oxford University Press, Oxford, pp. 1-48.

Ebert, K. H., 1991. Vom Verbum dicendi zur Konjunktion - Ein Kapitel universaler Grammatikalisierung. In: Bisang, W., Rinderknecht, P. (Eds.), Von Europa bis Ozeanien - von der Antonymie zum Relativsatz, Gedenkschrift für Meinrad Scheller. Arbeiten des Seminars für Allgemeine Sprachwissenschaft 11. Zurich: Universität Zürich, pp. 77-95.

Frajzyngier, Z., 1991. The de dicto domain in language. In: Closs Traugott, E., Heine, B. (Eds.), Approaches to grammaticalization, vol. 1. John Benjamins, Amsterdam, pp. 219-251. 
Güldemann, T., 2008. Quotative indexes in African languages: a synchronic and diachronic survey. Empirical Approaches to Language Typology, vol. 34. Mouton de Gruyter, Berlin (= Habilitation thesis 2001).

Heine, B., Claudi, U., Hünnemeyer, F., 1991. Grammaticalization: A conceptual framework. University of Chicago Press, Chicago.

Heine, B., Kuteva, T., 2005. Language contact and grammatical change. Cambridge University Press, Cambridge.

Heine, B., Kuteva, T., 2003. On contact-induced grammaticalization. Studies in Language 27.3, $529-572$.

Heine, B., Reh, M., 1984. Grammaticalization and reanalysis in African languages. Buske: Hamburg.

Herskovits, M., Herskovits, F. S., 1936. Suriname folk-lore. Columbia University Press, New York.

Kinyalolo, K. K. W. 1993. On some syntactic properties of mว̀ in Fon. Lingua 91, 201-233.

Klamer, M., 2000. How report verbs become quote markers and complementisers. Lingua 110, $69-98$.

Lefebvre, C., Brousseau, A-M., 2002. A grammar of Fongbe. Mouton de Gruyter, Berlin.

Lefebvre, C., Loranger, V., 2008. A diachronic and synchronic account of the multifunctionality of Saramaccan táa. Linguistics 46.6, 1167-1228.

Lefebvre, C., Loranger, V., 2006. On the properties of Saramaccan FU: Synchronic and diachronic perspectives. Journal of Pidgin and Creole Languages 21.2, 275-336.

Lord, C., 1993. Historical change in serial verb constructions. John Benjamins, Amsterdam. 
Lord, C., 1976. Evidence for syntactic reanalysis: From verb to complementizer in Kwa. In: Steever, S. B., C.A. Walker and Mufwene, S.S. (Eds.), Papers from the parasession on diachronic syntax. Chicago Linguistic Society, Chicago, pp. 179-191.

McWhorter, J. H., 1992. Substratal influence on Saramaccan serial verb constructions. Journal of Pidgin and Creole Languages 7, 1-53.

Migge, B., 1998. Substrate Influence in the Formation of the Surinamese Plantation Creole: A Consideration of Sociohistorical Data and Linguistic Data from Ndyuka and Gbe. Unpublished Dissertation, The Ohio State University.

Migge, B., 2006. Tracing the origin of modality in the creoles of Suriname. In: Deumert, A., Durrleman-Tame, S. (eds.), Structure and variation in contact languages. John Benjamins, Amsterdam, pp. 29-59.

Migge, B., Smith, N., (Eds.). 2007. Substrate influence in creole genesis; Special Issue of Journal of Pidgin and Creole Languages, vol. 22(1).

Migge, B., Winford, D., 2009. The origin and development of possibility in the creoles of Suriname In: Selbach, R., Cardoso, H., van den Berg, M. (Eds.). Gradual creolization. John Benjamins, Amsterdam, pp. 129-154.

Noonan, M., 1985. Complementation. In: Shopen, T. (Ed.), Language typology and syntactic description, Vol. II, Complex constructions. Cambridge University Press, Cambridge, pp. $42-140$.

Nylander, D., 1985. Serial verbs and the Empty Category Principle in Krio. Canadian Journal of Linguistics 30.1, 15-31.

Osam, E. K., 1998. Complementation in Akan. Journal of African Languages and Linguistics 19.1: 21-43. 
Osam, E. K., 1996. The history of the Akan complementizer. Journal of Asian and African Studies 51: 93-103.

Osam, E. K., 1994. Aspects of Akan grammar - a functional perspective. Unpublished PhD thesis, University of Oregon, Eugene.

Pienemann, M., 1998. Language processing and second language development: Processability Theory. John Benjamins, Amsterdam.

Plag, I.. 1995. The emergence of taki as a complementizer in Sranan: On substrate influence, universals, and gradual creolization. In: Arends, J. (Ed.), The early stages of creolization. John Benjamins, Amsterdam, pp. 113-148.

Plag, I., 1993. Sentential complementation in Sranan: On the formation of an English-based creole language. Niemeyer, Tübingen.

Plag, I., 1992. From speech act verb to conjunction: The grammaticalization of taki in Sranan. Journal of Pidgin and Creole Languages 7.1, 55-73.

Saxena, A., 1995. Unidirectional grammaticalization: Diachronic and synchronic evidence. Sprachtypologie und Universalienforschung 48, 350-372.

Schumann, C.L. 1783. Neger-Englisches Wörterbuch. Editio Tertia. MS. In: Kramp, A., 1983, Early creole lexicography: A study of C.L. Schumann's manuscript dictionary of Sranan. Diss. Rijksuniversiteit Leiden.

Sebba, M., 1987. The syntax of serial verbs. John Benjamins, Amsterdam.

Sranan Tongo - $\quad$ English Online Interactive Dictionary. http://www.sil.org/americas/suriname/sranan/english/srananengdictindex.html

Tossa, C. Z., 1994. Adjonctions et series verbales dans les langues gbé. Unpubllished Dissertation, Université d'Ottawa, Ottawa. 
Van Coetsem, F., 2000. A General and Unified Theory of the Transmission Process in Language Contact. Universitätsverlag, C. Winter, Heidelberg.

Van Coetsem, F., (1988). Loan phonology and the two transfer types in language contact. Foris, Dordrecht.

van den Berg, M., 2007. A grammar of early Sranan. Drukkerij Manta, Zetten (NL)..

van Dyk, P., 1765. Nieuwe en nooit bevoorens geziene onderwijzinge in het Bastert Engels, of Neeger Engels, zoo als hetzelve in de Hollandsze colonien gebruikt word. Jacobus van Egmont, Amsterdam.

Veenstra, T., 1996. Serial verbs in Saramaccan. Predication and creole genesis. ICG Printing, Dordrecht.

Winford, D., (to appear 2012). Substrate influence and universals in the emergence of contact Englishes: Reevaluating the evidence. In: D. Schreier and M. Hundt (eds.), English as a contact language. Cambridge University Press, Cambridge.

Winford, D., 2008. Processes of creole formation and related contact-induced language change. Journal of Language Contact Thema 2, 124-145.

Winford, D., 2000. Irrealis in Sranan: Mood and modality in a radical creole. Journal of Pidgin and Creole Languages 15.1, 63-125.

Winford, D., 1993. Predication in Caribbean English creoles. Amsterdam: John Benjamins. 